\title{
Influence of Assistive Technology for the Maintenance of the Functionality of Elderly People: an Integrative Review

Eliane de Sousa Leite ${ }^{1}$, Tatiane Peixoto Rodrigues ${ }^{2}$, Maria do Carmo Andrade Duarte de Farias ${ }^{3}$, Maria Adelaide Silva Paredes Moreira ${ }^{4}$,Greicy Kelly Gouveia Dias Bittencourt ${ }^{4}$, Francisca Bezerra de Oliveira', Clélia Albino Simpson ${ }^{5}$, Antonia Oliveira Silva ${ }^{4}$

\section{Abstract.}

Introduction: Assistive technology consists of resources and services that contribute to provide or extend functional skills and promote independence and social inclusion of disabled or elderly.

Objective: Identifying the knowledge produced in the scientific literature about contributions of assistive technology for the maintenance of the old functionality.

Method: It was conducted an integrative literature review in the following databases: PubMed, Cochrane and LILACS, in May 2015, using the controlled descriptors: Aged, Aging, Self-help devices, Assistive Devices, Assistive Equipment and Assistive Technology. There were selected 13 items based on inclusion criteria.

Results: There were identified the following classifications in assistive technology: augmentative and alternative communication, environment control systems, mobility aids, postural adequacy, architectural projects for accessibility and sports and leisure.

Conclusion: The use of assistive technology allows the elderly to develop the functional activities of daily living safely, increase their independence and autonomy, prevent comorbidities and thereby contribute to improving the quality of life and social inclusion of the elderly.
1 Academic Unit of Nursing, Teacher's Training Center, Federal University of Campina Grande. Cajazeiras, Paraiba, Brazil.

2 Graduate Program in Nursing, Federal University of Paraiba. João Pessoa, Paraiba, Brazil.

3 Academic Unit of Life Sciences, Teacher's Training Center, Federal University of Campina Grande. Cajazeiras, Paraiba, Brazil.

4 Academic Unit of Life Sciences, Teacher's Training Center, Federal University of Paraiba. João Pessoa, Paraiba, Brazil.

5 Academic Unit of Life Sciences, Teacher's Training Center, Federal University of Rio Grande do Norte, Natal, Rio Grande do Norte, Brazil.

Contact information:.

Eliane de Sousa Leite.

Æ elianeleitesousa@yahoo.com.br

Keywords.

Elderly; Assistive technology; Self-help equipment; Personal autonomy; Review of literature. 


\section{Introduction}

Throughout history man has made use of technology to improve their quality of life, but only in the last three decades, this set of resources and services was renamed Assistive Technology (AT) and can be considered as a constituted process by a set of abstract and concrete actions and has purposes. AT permeates the entire health work process. From the main idea, the implementation is an essential tool for health care as well as being highlighted in relations between users and professionals [1].

This name was defined in the United States in 1988. In Brazil, the terminology was made official by the Committee on Technical Assistance (CAT) of the National Secretariat for the Promotion of Rights of Persons with Disabilities, and is considered an interdisciplinary area of knowledge that encompasses product, resources, methodologies, strategies, practices and services to promote the functionality related activities and participation of people with disabilities, disability or reduced mobility and thus provide them with autonomy, independence, quality of life and social inclusion [2].

The AT is relatively new term in Brazil and is used to identify the arsenal of resources and services; it can be characterized also as an area that has stimulated new researches for the development of equipment to encourage an increase, maintenance and improvement of the functional abilities of people with disabilities or elderly, enabling effective conditions for improving the quality of life, to foster greater autonomy and allow them to become more productive.

With regard to aging, despite efforts made to ensure an active and healthy old age, most people aged 60 and over experienced at least one weakness during this phase of life, which makes the elderly decrease or lose its functionality [3].

Therefore, when the elderly is compromised with its functionality, usually the family seeks help in instruments and equipment offered by the $A T$, to enhance this functionality and, therefore, perform their basic and instrumental activities of daily living.
Therefore, the use of AT is a necessary strategy for the active inclusion of older people in society, at home, long term care facilities or hospitals [4].

In Brazil, the elderly population uses the restricted mode of AT, both high-tech instruments as less sophisticated, like the help to perform activities of daily living. This fact is due to the lack in the knowledge of this population to acquire such devices, especially by less favored social classes economically.

Regarding the professionals working with the elderly, a study conducted in Brazil in primary care, shows that they have a superficial knowledge of these technologies, so its indication for the elderly is still limited [5].

About the use of AT for the elderly, this study presents social and academic relevance, an integrated perspective in the face of health care and make it possible to know what are the main contributions from these new technologies and their impact on the maintenance of autonomy, functionality and social inclusion of older people.

Thus, the present study aims to provide subsidies that allow reflections for the development or use of integrative reviews in the health scenario of the elderly. Thus, the goal is to identify the knowledge produced in the scientific literature about the contributions of assistive technology in maintaining the old functionality.

\section{Method}

There was used the integrative review to be a specific method, which summarizes past empirical and theoretical literature to provide a comprehensive understanding of a particular phenomenon [6].

This method aims to drawing an analysis about the knowledge built on previous research on a particular topic; enabling the synthesis of results presented by several studies published once, allowing the generation of new knowledge $[7,8]$.

When performing an integrative review of literature it is important to follow a rigorous methodological process, noting clearly described steps to 
enable effective analysis and synthesis of scientific knowledge that has been produced on the subject to be studied. For the production of this integrative review, there were used six stages described below [9].

\section{First stage. Identification of the theme and selection of the guiding question for the research}

When thinking about the relevance of AT for the improvement of the elderly and their social inclusion functionality, it made up the question that guided this study: "What are the contributions of assistive technology to increase functionality or maintenance in the elderly?"

\section{Second stage. Criteria for selection of the sample}

The survey was conducted in the month of May 2015, starting with the database of the Virtual Health Library (BVS): Latin American and Caribbean Health Sciences (LILACS); the international database Medical Plubished - serve of the US National Library of Medicine (PubMed) and the Cochrane Library. The descriptors used were: Aged, Aging, Self-help Devices, Assistive Devices, Assistive Equipment and Assistive Technology, in English, to international databases, and in Portuguese for the Brazilian.

The criteria used for inclusion of articles were published between 2005 and 2014, which they referred to assistive technology for the elderly; provide free availability of the content of their abstracts and full text; are written in Portuguese, English or Spanish; behave in their sample persons aged from 60 years old; they have been designed in order to obtain results with relevant evidence levels; original studies of quantitative and qualitative approach, systematic reviews.

In international basis PUBMED found 2497 articles with the use of descriptors. Applied the inclusion criteria there were obtained nine articles. In the Cochrane Library, using the controlled descriptors emerged 11 articles, three of which met the re- search inclusion criteria. LILACS found nine articles, one of which met the inclusion criteria.

\section{Third stage. Identification of selected studies}

After the final selection of the articles, the same were assessed in its entirety and produced nine articles in PubMed, Cochrane Library and three in LILACS. Detailed were read such articles, analyzing whether they responded to the main question of the research

\section{Fourth Stage. Characterization of the articles}

At this stage, there was used an instrument validated by Ursi [10], to collect important information about the articles selected for this integrative review, containing the following items: year of publication, article ID, title, author, type of study, level of evidence, journals, classification of AT used in the study, objectives and key results. An array of synthesis with the articles and relevant points contained therein guided the thorough analysis of their content and the synthesis of these, taking into account the level of evidence and relevance to make reference to the conclusions reached.

\section{Fifth Stage. Analysis and interpretation of results}

We performed a critical analysis of the selected articles if elucidating them different results in order to get the answer to the question of the study. Information was synthesized in order to present consistent information of the work and confront dissenting.

\section{Sixth Stage. Presentation of the knowledge synthesis}

The conclusions were based on evidence obtained and the critical analysis of the results found on items that were part of this research. 


\section{Results}

\section{Characterization of the articles analyzed} In this study, there were analyzed 13 articles. Table 1 shows the distribution of the articles found in databases from 2005 to 2014.

With regard to the year of publication of the international and national journals, the years 2011, 2012, 2013 and 2014 had higher numbers of ar- ticles published in the area and there is a predominance of international databases. It is observed that the growth of these publications is recent; this comes as this is an area of study that is on the rise and is considered interdisciplinary area, allowing the involvement of many professionals in the work of AT.

Table 2 depicts the items as identification and title, type of study, evidence levels and journals where

Table 1. Distribution of articles found in the period from 2005 to 2014, according to the databases searched.

\begin{tabular}{l|c|c|c|c|c|c|c|c|c|c|c|}
\hline & \multicolumn{10}{|c}{ Number of articles published per year } \\
\cline { 2 - 15 } & $\mathbf{2 0 0 5}$ & $\mathbf{2 0 0 6}$ & $\mathbf{2 0 0 7}$ & $\mathbf{2 0 0 8}$ & $\mathbf{2 0 0 9}$ & $\mathbf{2 0 1 0}$ & $\mathbf{2 0 1 1}$ & $\mathbf{2 0 1 2}$ & $\mathbf{2 0 1 3}$ & $\mathbf{2 0 1 4}$ & Total \\
\hline & $\mathrm{n}$ & $\mathrm{n}$ & $\mathrm{n}$ & $\mathrm{n}$ & $\mathrm{n}$ & $\mathrm{n}$ & $\mathrm{n}$ & $\mathrm{n}$ & $\mathrm{n}$ & $\mathrm{n}$ & $\mathrm{n}$ \\
\hline PUBMED & - & 01 & - & - & - & 01 & 02 & 01 & 02 & 02 & 09 \\
\hline Cochrane & - & - & - & - & - & - & - & 01 & 01 & 01 & 03 \\
\hline LILACS & - & - & - & 01 & 00 & - & - & - & - & - & 01 \\
\hline Total & 00 & 01 & 00 & 01 & 00 & 01 & 02 & 02 & 03 & 03 & 13 \\
\hline
\end{tabular}

Table 2. Distribution of articles, addressing the AT for the elderly, according to ID and title, type of study, níveco.

\section{Identification/Article Title}

Exploring the usability of a videophone mock-up for persons with dementia and their significant others [16]

Acceptance of an assistive robot in older adults: a mixedmethod study of human-robot interaction over a 1-month period in the Living Lab setting [17]

Deployment of assistive living technology in a nursing home environment: methods and lessons learned [18].

Evaluating the Effectiveness of a Memory Aid System [19].

Prevalence and facility level correlates of need for wheelchair seating assessment among long term care residents [20].

Geriatric Assistive Devices [21]

Sliding and pressure evaluation the conventional and $\checkmark$-shaped seats of reclining wheelchairs for stroke patients with flaccid hemiplegia: a crossover Trial [22].

A Randomized Clinical Trial on Preventing Pressure Ulcers with Wheelchair Seat Cushions [23].

\begin{tabular}{|c|c|c|}
\hline Type of the study & $\begin{array}{l}\text { Level of } \\
\text { Evidence } \\
\text { [11] }\end{array}$ & Journal \\
\hline Qualitative Study & IV & BMC Geriatrics \\
\hline $\begin{array}{l}\text { Quantitative and } \\
\text { Qualitative Study }\end{array}$ & IV & Clin Interv Aging \\
\hline Qualitative Study & IV & $\begin{array}{l}\text { BMC Medical Informatics } \\
\text { and Decision Making }\end{array}$ \\
\hline $\begin{array}{l}\text { Quantitative study of } \\
\text { experimental type }\end{array}$ & IV & Gerontology \\
\hline Cross-sectional Study & IV & Gerontology \\
\hline
\end{tabular}

Observational Study

IV American Family Physician

Experimental Study II Journal of Neuro Engineering and Rehabilitation

Randomized

Clinical Trial
II J Am Geriatric Soc. 


\section{Identification/Article Title}

\section{Type of the study}

Experimental Study

Public telesurveillance service for frail elderly living at home, outcomes and cost evolution: a quasi-experimental design with two follow-ups [24]

Smart Grab Bars: A Potential Initiative to Encourage Bath Grab Bar Use in Community Dwelling Older Adults [25].

Efficacy of simple home-based technologies combined with a monitoring assistive center in decreasing falls in a frail elderly population (results of the Esoppe study) [26].

Assistive technology of Musical Experiences in elderly patients with vocal recovery from Parkinson's disease [27].

Factors influencing acceptance of technology for aging inplace: A systematic review [28].
Prospective cohort study

Experimental study non-randomized

Systematic Review

Level of

Evidence [11]

II

Health and Quality of Life

\begin{tabular}{ll|l} 
Experimental Study $\quad \| \quad$ Assistive Technology: The
\end{tabular} Official Journal of RESNA

II Archives of Gerontology and Geriatrics

III

Journal of Geriatrics and Gerontology

International Journal of Medical Informatics

Source: PubMed, LILACS, Cochrane, 2005-2014

they were published. By analyzing the designs of the studies there were observed some publications with a low level of scientific evidence in qualitative and quantitative research, highlighting transversal and observational studies. However, research found a high level of evidence, such as the systematic review, randomized, prospective cohort study, among others [11]. Denotes the importance of conducting studies using precise methodological designs and enable strong level of evidence to strengthen the knowledge of the proposed subject matter.

With respect to journals in which the articles were published, the highest incidence of publication was given in international journals, as twelve of the articles selected for the study are indexed in PubMed and the Cochrane Library basis. The national article indexed in the database LILACS, is published in the Journal of Geriatrics and Gerontology

In Table $\mathbf{3}$ follows the classification of the AT used in each study, the proposed objectives and the main results. Regarding the Classification of Assistive Technology resources, there are organized or classified according to functional objectives as intended. Several AT classifications have been developed for different purposes and quoted ISO 9999/2011 [12] as important international classification resources, applied in several countries.
The classification that was used for this study has a didactic purpose and was built by José Tonolli and Rita Bersch [13] in 1998, in each topic considers the existence of resources and services; it was designed based on other classifications used in AT databases and especially from the formation of the authors in the Certification Program Applications of Assistive Technology - ATACP the California State University Northridge, College of Extended Learning and Center on Disabilities [13].

This classification was used by the Ministry of Finance; Science, Technology and Innovation and the National Secretariat of the Presidency Human Rights of the Republic/Brazil in the publication of Administrative Rule 362 of 24${ }^{\text {th }}$ October, 2012; which deals with the line of subsidized credit for the acquisition of goods and assistive technology services for the disabled and the list of goods and services [15].

In the articles reviewed for this study it was possible to find the following AT ratings: augmentative and alternative communication, an article [16], environment control systems, five articles [17, 18, 19, 24, 26], mobility aids, three papers [20, 21, 22], postural adjustment, an article [23], architectural plans for accessibility, an article [25] sports and leisure, an article [28] and another that did not apply in the classification [28]. 
Table 3. Summary of the studies reviewed, addressing the AT for the elderly, as the classification [15], objectives and results obtained.

\begin{tabular}{|c|c|c|c|}
\hline Classification of the AT & AT used & Objectives & Results \\
\hline $\begin{array}{l}\text { Augmentative and } \\
\text { alternative communication } \\
\text { [16] }\end{array}$ & $\begin{array}{l}\text { Videophone } \\
\text { mock-up }\end{array}$ & $\begin{array}{l}\text { - Assessing the usability of a mock- } \\
\text { up of the touch screen videophone } \\
\text { for people with dementia and their } \\
\text { significant }\end{array}$ & $\begin{array}{l}\text { - Participants had positive attitude using the videophone; realized that the equipment was } \\
\text { useful, enjoyable and easy to use, although at the beginning of the tests had difficulty in } \\
\text { understanding how to deal with some functions; } \\
\text { - The joy of senior citizens being able to use the videophone seemed so strong that balanced } \\
\text { the difficulties faced by them. }\end{array}$ \\
\hline $\begin{array}{l}\text { Environmental control } \\
\text { systems [17] }\end{array}$ & $\begin{array}{l}\text { Robot Kompaï } \\
\text { Robot }\end{array}$ & $\begin{array}{l}\text { - We aimed to observe robot-acceptance } \\
\text { in older adults, particularly subsequent } \\
\text { to a 1-month direct experience with a } \\
\text { robot. }\end{array}$ & $\begin{array}{l}\text { - Users interact with the robot through voice and the screen is touch-sensitive; } \\
\text { - The participants demonstrated a low intended to use the assistive robot and showed } \\
\text { negative attitudes in relation to the machine, they hadn't realized its usefulness; } \\
\text { - They found the robot easy to use, fun and non-threatening; Others showed a lack of interest } \\
\text { or motivation, reluctance around the technology, due to a fear of dehumanization of society; } \\
\text { - For participants, the only condition to use an assistive robot is when an elderly person } \\
\text { becomes totally dependent. }\end{array}$ \\
\hline $\begin{array}{l}\text { Environmental control } \\
\text { systems [18] }\end{array}$ & $\begin{array}{l}\text { Implementation } \\
\text { of a system for } \\
\text { environment/ } \\
\text { home health } \\
\text { care }\end{array}$ & $\begin{array}{l}\text { - Deploy a system for assistive } \\
\text { environment in a nursing home and } \\
\text { assess its performance and usability in } \\
\text { real conditions. }\end{array}$ & $\begin{array}{l}\text { - Caregivers should only interfere only when the elderly cannot solve your problem; } \\
\text { - The system for AT environment enables the elderly with dementia and eases the workload of } \\
\text { caregivers; } \\
\text { - Detected problems in home health care: the elderly bathe repeatedly and remain in the } \\
\text { shower for a long time, because they forget that had already showered; linking and forgets } \\
\text { to close; wear clothes from other seniors, do you recognize your; wandering and walking } \\
\text { around the room during the night and can't sleep and lie in the wrong bed; } \\
\text { - The caretakers make reminders with the activities that they need to perform in order for } \\
\text { them to develop some level of independence. }\end{array}$ \\
\hline $\begin{array}{l}\text { Environmental control } \\
\text { systems [19] }\end{array}$ & $\begin{array}{l}\text { InBad: touch } \\
\text { screen installed } \\
\text { in a mirror }\end{array}$ & $\begin{array}{l}\text { - Evaluate the effectiveness of a memory } \\
\text { aid system, the InBad (Eng. InBath), for } \\
\text { bathroom-related daily care. }\end{array}$ & $\begin{array}{l}\text { - InBad includes a touch screen, installed in a mirror, this allows the user to interact with the } \\
\text { system; } \\
\text { - The system seizes the behavior and the user's old routine and in the early stages of dementia, } \\
\text { to then detects deviations from the standard. } \\
\text { - In addition to maintaining the privacy of the elderly, the system can potentially reduce the } \\
\text { workload of caregivers; } \\
\text { - The results suggest that this type of TA, allows the elderly to remain safe and independent in } \\
\text { your own home. }\end{array}$ \\
\hline
\end{tabular}




\begin{tabular}{|c|c|c|c|}
\hline Classification of the AT & AT used & Objectives & Results \\
\hline $\begin{array}{l}\text { Environmental control } \\
\text { systems [24] }\end{array}$ & $\begin{array}{l}\text { Communication } \\
\text { Technology } \\
\text { Service }\end{array}$ & $\begin{array}{l}\text { - Document outcomes and cost } \\
\text { evolution of a nurse-staffed } \\
\text { telesurveillance system for frail elderly } \\
\text { living at home. }\end{array}$ & $\begin{array}{l}\text { - The services provided by tele surveillance are based on communication technology; is a } \\
\text { service provided by medicine and nursing, which allows to monitor patients at home; are } \\
\text { offered emergency care and health guidance in General; } \\
\text { - The service showed that health guidelines that the elderly received at home decreased the } \\
\text { hospitalizations; burden of care offered by the caregiver to the elderly; decrease in the level } \\
\text { of anxiety and about the safety of your family member; } \\
\text { - The study showed that the tele communication surveillance system for the elderly is effective } \\
\text { and efficient. }\end{array}$ \\
\hline $\begin{array}{l}\text { Environmental control } \\
\text { systems [26] }\end{array}$ & $\begin{array}{l}\text { Automated } \\
\text { beam } \\
\text { associated with } \\
\text { tele assistance } \\
\text { service }\end{array}$ & $\begin{array}{l}\text { - Evaluate the efficacy of light path } \\
\text { coupled with tele-assistance service for } \\
\text { preventing unintentional falls at home } \\
\text { in a frail elderly population. }\end{array}$ & $\begin{array}{l}\text { - The incidence of falls at home was lower in the exposed group }(30,9 \%) \text { than in the non- } \\
\text { exposed group }(50,0 \%) \text {. } \\
\text { - Reduction in the risk of hospitalization for falls at home in the exposed group }(9,6 \%) \text { in } \\
\text { comparison with the unexposed group }(25,0 \%) \text {. } \\
\text { - There was an acceptance rate of } 97,3 \% \text {. }\end{array}$ \\
\hline $\begin{array}{l}\text { Mobility aid } \\
\text { [20] }\end{array}$ & Wheelchairs & $\begin{array}{l}\text { - Identify the prevalence of need for } \\
\text { wheelchair seating intervention among } \\
\text { residents in long-term care facilities in } \\
\text { Vancouver and explore the relationship } \\
\text { between the need for seating } \\
\text { intervention and facility level factors. }\end{array}$ & $\begin{array}{l}\text { - Wheelchairs are prescribed without assessment by health professionals without training in } \\
\text { the area and that contributes to future health problems; Results of misuse of wheelchair: } \\
\text { discomfort, bad positioning, impaired mobility and pressure ulcers; } \\
\text { - Health condition that took the elderly to use the wheel chair: stroke and other neurological } \\
\text { disorders, Alzheimer's, arthritis, amputation, and Arthroplasty fractures; } \\
\text { - The availability of occupational therapist to provide wheelchair and seating evaluation is } \\
\text { limited and therefore contributes to the acquisition by the family or responsible for the } \\
\text { elderly, inadequate wheelchair. }\end{array}$ \\
\hline $\begin{array}{l}\text { Mobility aid } \\
{[21]}\end{array}$ & $\begin{array}{l}\text { Cane, crutches, } \\
\text { walker }\end{array}$ & $\begin{array}{l}\text { - Evaluate the use of assistive devices } \\
\text { used by elderly people with impaired } \\
\text { mobility. }\end{array}$ & $\begin{array}{l}\text { - Older people with AIDS are not instructed on the proper use and often have devices that are } \\
\text { inadequate, damaged or are incorrect height; } \\
\text { - Specialized professionals should routinely evaluate the auxiliary devices; } \\
\text { - Assistive devices are used to increase the base of support, improve balance avoiding fall, } \\
\text { redistribute weight, relieve joint pain and increase the activity and independence; } \\
\text { - Physiological benefits: improved cardiorespiratory function, circulation and prevents } \\
\text { osteoporosis. }\end{array}$ \\
\hline
\end{tabular}




\section{Classification of the AT}

Mobility aid

[22]

Posture

[23]

accessibility

[25]

Sport and Leisure

[27]

Does not apply[28]

Does not apply

Conventional

wheelchair and

wheelchairs

with V-shaped

seats

Seat cushion

for wheelchairs

Intelligent

support bar

Music therapy

\section{Objectives}

\section{- Develop, adapt and test an assistive} technology based on music therapy, aiming at the improvement of the voca emission, respiratory dynamics, voca performance and social inclusion in

elderly people affected by Parkinson's. increase grab bar use by seniors and to determine the efficacy of different cues (auditory, visual, and audiovisual combination) on the frequency of use of a grab bar.

Provide an overview of the facilitators in the implementation of technology factors in the elderly of community housing. - Provide directions for future research of technology acceptance in this particular group.

\section{Results}

- V-shaped Seats reduce noticeably the slide into front of elderly patients with STROKE and hemiplegia, flaccid (compared to conventional wheel chair) indicating that V-shaped seats can help prevent sacral pressure that leads to the development of pressure ulcers, in that area.

- The study showed that the professionals must be cautious and prescribe only wheelchairs with seats in $V$ for patient with STROKE, because with this caution prevents health problems later.

Skin protection cushions are designed to maintain the integrity of the tissue, reducing pressures near bony prominences accommodating orthopedic deformities;

- The intervention protocol used for the participants of this study does not represent the practice used in the daily routine in nursing homes;

- This was the first clinical trial that tested the effectiveness of seat cushions to wheelchair using segmented foam pad, which had positive results

- The intelligent support bar increased by $39 \%$ to frequency of use by the elderly, that effect was maintained even after the removal of the information.

- The acoustic signal proved to be more effective on the frequency of use of the prototype.

Seven seniors showed improvements in emission vocals, four elderly kept the previous aspects and only one elderly person had decreased amplitude in the volume of issuance of the spoken voice.

Some participants showed improvements in respiratory dynamics. However, many maintained its previous state.

Assistive devices are used to increase the base of support, improve balance avoiding fall, redistribute weight, relieve joint pain and increase the activity and independence; Physiological benefits: improved cardiorespiratory function, circulation and prevents osteoporosis.

- The acceptance of technology is influenced by six themes: concerns about the technology as the cost; Benefits expected (e.g. guarantee greater safety); Perception of the need for technology (referring to the personal perception about the State of health); Alternatives to the use of this technology, being reduced if the elderly have the help of family members; Social influence of family, friends or professionals and personal/cultural Characteristics of the elderly. 
Concerning the objectives of the studies there were the most varied: assess, investigate, deploy environments systems; identify, compare the various mobility aid equipment; determine the effectiveness of equipment/instruments for proper positioning; evaluate the effectiveness of architectural projects and develop and test a AT based in sport and leisure.

\section{Discussion}

We live in a time when technology is highly valued and is an area on the rise driven mainly by the paradigm of social inclusion, which advocates the participation of people with disabilities or the elderly in the various environments of society [14].

Technology is considered assistive when it is used to assist in the functional performance of activities, reducing disabilities to perform activities of daily living and everyday life in the various areas of daily life [14]. The use of assistive technology involves the expansion of the functional abilities of the individual, providing the restoration of deficient functions or carrying out activities that are prevented as a result of congenital or acquired deficiencies during the aging process [15].

\section{Specifications of the articles reviewed}

In the selected articles, it was observed that there were used for various types of assistive technology tools, among which the study [16] used the augmentative and alternative communication with videophone mock-up for elderly people with dementia. The mock-up facilitates communication of the elderly as it is connected to a computer monitor touch. The device receives and makes calls to people in their contact list and emergency calls through icons arranged on the screen. Dementia can cause the old have great difficulty using a landline phone as a result of memory loss. Thus, this feature is a benefit for the elderly demented because they ask for help when needed and keep their social network, avoiding the isolation and keeping themselves safe and independent in their homes.

As part of the environmental control system of classification, researchers [17] used a robot assistance to support and assist elderly people with mild cognitive impairment in their daily tasks. Corroborating this research, scholars [18] equate a nursing home for the elderly with dementia in Singapore, with the resources of assistive technology in order to enable the elderly to perform their activities of daily living (ADLs). As a result, these studies showed a decrease in caregiver workload because using the AT, the elderly increased independence to perform ADL and their physical and psychological well-being.

In another study [19], using the environment control system feature, the authors evaluated the effectiveness of a memory aid system in elderly people with cognitive impairment. The InBad system there was installed in the bathroom mirror, allowing the elderly to interact with it. Thus, the system learns its patterns of behavior and routine in order to notify them of a task forgotten by them. The results suggest that the AT has the potential to allow seniors to perform various activities, among them: body care, simple arrangement of the house and taking medication, staying safe and independent in their own home.

In this same classification, researchers [24] have used communications technology to evaluate a remote monitoring service to monitor weak elderly in their homes, and to observe their effectiveness and cost. The tele is a service provided by the medical and nursing that allows you to track elderly at home, doing service of general guidance and emergency. The contributions of this study were effective and efficient. One benefit was the reduction of institutionalization of the elderly, as this system provided the permanence in their homes, carrying out their activities safely, guided by professionals; another benefit was observed reducing caregiver workload and especially the security offered to 
assisted individuals and the welfare of the whole family. Otherwise, the study conducted in France [26] evaluated the effectiveness of a light beam installed along with the tele assistance service for the prevention of falls in a frail elderly population living at home. On the contributions of using this assistive device there was a significant reduction in the incidence of accidental falls during the bath and generally.

The mobility aid classification, a research [20] found the prevalence of the need to use wheelchairs for seniors living in long-stay institutions, observing the prescription, the misuse results and health condition that took the elderly in need of such an tool. Corroborating this study, researchers at the Medical School in Vancouver [21] evaluated the use of assistive devices, canes, crutches and walkers used to increase the base of support of elderly patients. The contributions of these studies warn that the professional should observe the physical strength of the patient, endurance, balance, cognitive function and environmental requirements in order to make the correct choice of mobility aid equipment. For the purpose of such devices it is to improve the balance, increase the activity and functional independence.

Regarding the mobility aid instruments, researchers [22] compared the difference between wheelchairs with seats $V$-shaped and conventional wheelchair in elderly patients with stroke and flaccid hemiplegia, which have the total balance to sit. They pointed out that $\mathrm{V}$-shaped seats in reclining wheelchairs, unlike the conventional help reduce the forward sliding of the patient, preventing the sacral pressure and, consequently, the rise of pressure ulcers.

As a postural adequacy of classification, a study [23] used is segmented foam pads for the elderly skin protection institutionalized that made daily use for six hours wheelchairs. The pads are designed to maintain the integrity of the skin, reducing pressures near bony prominences, orthopedic deformities and give comfort and safety. The result of the study showed that despite being wheelchair you need a stable and comfortable posture, making it difficult to carry out any task when you are insecure about the possible falls or feeling discomfort.

The architectural plans for accessibility are another form of classification of AT, which ensures access, functionality and mobility to all people, regardless of their physical and sensory condition. In this sense, the research conducted in the Occupational Therapy Program of Rehabilitation Sciences at the University of Ottawa [25] sought to find what signal (visual or audible), issued by an intelligent handlebar prototype installed in the bathroom to prevent falls, would be more effective to increase the use of this instrument by the elderly. The study results showed that intelligently support bar increased by $39 \%$ the frequency of use by the elderly and hence there was a decrease of falls in the bathroom.

With regard to technology geared towards sports and recreation, authors [27] used the music for elderly patients with Parkinson's disease. The music offered important aids, highlighting: development and improvement of vocal, respiratory dynamics, vocal performance and social inclusion.

One of the studies reviewed [28] does not apply for the classification adopted by José Tonolli and Rita Bersch [13] for this study. This was a systematic review was to identify the factors that facilitate the use of TA in elderly residents of a community and provide directions for future technology acceptance research, in the investigated group. The result of this research showed that the acceptance of the technology is influenced by several factors: concerns about the cost; expected benefits; and perception of their need, related to health. Pointed out, also, that the use of AT is reduced when the elderly is not geared towards resource utilization, no help from family, friends, health care professionals; in addition to vary according to the personal and cultural characteristics of this population. 
Before the analysis of the selected articles, we observe the various instruments and equipment that are used by the AT and to act as a key factor to modify the process of disability in the elderly, reducing the severity of physical, mental or cognitive.

\section{Synthesis of knowledge about the AT and its contributions to the functionality of the older person}

Regarding the use of AT for the elder it was found that many had positive attitudes towards equipment, instruments and services. However, others have shown lack of interest and motivation and reluctance to use the technology, due to the lack of guidance from professionals who attended them and the fear of stigmatization by society.

Elderly people affected with dementia and some chronic diseases gradually lose their autonomy as the basic and instrumental activities of daily living. Therefore, they need supervision and assistance from family members or professional caregivers. Often, this care can lead to psychological stress and physical illness caregiver. Thus, an environment adapted to AT equipment has the potential to improve the functionality, autonomy and independence of the elderly, to carry out their activities and thereby ease the workload and stress of caregivers.

Evidence observed in the studies was the misuse of aid AT equipment for mobility for the elderly. Due to the poor health condition of the elderly is taken to use this type of resource, most of the time, acquired by the family or prescribed, rated by qualified health professionals. Consequently, the misuse of equipment contributes to health problems such as: functional impairment, diseases joints, reduced mobility, pressure ulcers, among others.

It is also observed, the benefit of AT to reduce the incidence of accidents from falls, hospitalizations and institutionalization. Consequently, reduce to costs in maintaining the health of the elderly.

Finally, various aspects are improved with the use of $A T$, especially the elderly functionality that are keeping their freedom to live alone and develop activities that give them pleasure; it can also be understood as the ability of any individual to adapt to everyday problems, despite having physical limitations, mental or social.

Thus, the use of AT is a necessary strategy for the active inclusion of the elderly in society, in long term care facilities in their own home and or even in hospitals.

\section{Conclusion}

The literature integrative review allows making some considerations about the scientific research that operates in this field:

- Despite growing demand in the use of AT approach in Brazil, there is an insufficient amount of professionals specialized in the Assistive Technology (AT) area;

- Researches concerning this subject are scarce, making it difficult to define and develop public policies in this area;

- It is necessary to raise awareness among health professionals of the benefits that the use of AT allows the elderly;

- Provide social inclusion of the elderly means the conquest and the practice of citizenship and in that sense the AT is an important tool that cannot be disregarded.

Thus, it is expected that through this discussion, professionals, managers and academic community are aware and induced the production of research in AT area and in the aging process in order to gradually cooperate for social inclusion and changes in the lives of elderly in our country. 


\section{References}

1. Galvão Filho TAA. Construção do conceito de Tecnologia Assistiva: alguns novos interrogantes e desafios. Revista entre ideias: Educação, Cultura e Sociedade. 2013; 2(1):25-42. Disponível em: http://www.galvaofilho.net/TA desafios.htm.

2. Comitê de Ajudas Técnicas (CAT). Secretaria Especial dos Direitos Humanos da Presidência da República (CORDE/SEDH/ PR). Ata da Reunião VII, de dezembro de 2007. Disponível em: http://www.infoesp.net/CAT Reuniao VII.pdf.

3. Papaléo Netto M. Tratado de gerontologia. 2. ed. rev. e ampl. São Paulo: Editora Atheneu. 2010.

4. Pelosi MB, Nunes LROP. Formação em serviço de profissionais da saúde na área de tecnologia assistiva: O papel do terapeuta ocupacional. Rev Bras Crescimento Desenvolv Hum. 2009; 19(3): 435-444. Disponível em: http://www.revistas.usp. br/jhgd/article/viewFile/19931/22009.

5. Andrade VS, Pereira LSM. Influência da tecnologia assistiva no desempenho funcional e na qualidade de vida de idosos comunitários frágeis: uma revisão bibliográfica. Rev. Bras. Geriatr. Gerontol. 2009; 12(1):113-122. Disponível em: http://www.crde-unati.uerj.br/img tse/v12n1/pdf/art 9.pdf.

6. Broome ME. Integrative literature reviews for the development of concepts. In: Rodgers BL, Castro AA. Revisão sistemática e meta-análise. 2006. Disponível em: http://www.researchgate. net/publication/238248432

7. Mendes KDS, Silveira RCCP, Galvão CM. Revisão integrativa: método de pesquisa para a incorporação de evidências na saúde e na enfermagem. Texto Contexto Enfermage. 2008; 17(4): 758764. Doi.org/10.1590/S0104-07072008000400018.

8. Polit DF, Beck CT. Using research in evidence-based nursing practice. In: Polit DF, Beck C. T. Essentials of nursing research. Methods, appraisal and utilization. Philadelphia: Lippincott Williams \& Wilkins, 2006. PMID: 11759419.

9. Botelho LLR, Cunha CCA, Macedo M. O método da revisão integrativa nos estudos organizacionais. Gestão e Soc. 2011; 5(11): 121-36. Disponível em: http://www.gestaoesociedade. org/gestaoesociedade/article/view/1220.

10. Ursi SE. Prevenção de lesões na pele no perioperatório: revisão integrativa de literatura. Dissertação (Mestrado em Enfermagem). Universidade de São Paulo, São Paulo, 2005. Disponível em: http://www.teses.usp.br/teses/disponiveis/22/22132/tde18072005-095456/pt-br.php.

11. Souza MT, Silva MD, Carvalho R. Revisão Integrativa: o que é e como fazer. Rev. einstein. 2010; 8(11): 102-6. Disponível em: http://www.astresmetodologias.com/material/O que e RIL.pdf.

12. ISO 9999: 2011. Norma Internacional de classificação. Disponível em: http://www.iso.org/obp/ui/\#iso:std:iso:9999:ed-5:v1:en
13. Bersch R. Introdução a Tecnologia Assistiva. Disponível em: www.assistiva.com.br/Introducao TA Rita Bersch.pdf, 2013.

14. Rodrigues PR, Alves LRG. Tecnologia Assistiva: uma revisão do tema. HOLOS. 2013; 29(6): 171. Disponível: http://www2.ifrn. edu.br/ojs/index.php/HOLOS/article/viewFile/1595/765.

15. Rocha EF, Castiglioni MC. Reflections on technological resources: aids techniques, assistive technology, technology of assistance and technology of support. Rev. Ter. Ocup. 2005; 16(3): 97-104. Disponível em: http://www.unicap.br/pergamum/ arquivos/155000/159800/90 159802.html.

16. Boman IL, Lundberg S, Starkhammar S, Nygard L. Exploring the usability of a videophone mock-up for persons with dementia and their significant others. BMC Geriatrics. 2014; 14(49): 6-11. Doi:10.1186/1471-2318-14-49.

17. Wu YH, Wrobel J, Cornuet M, Kerhervé H, Damnée S, Rigaud AS. Acceptance of an assistive robot in older adults: a mixedmethod study of human-robot interaction over a 1-month period in the Living Lab setting. Clin Interv Aging. 2014; 8(9): 801-11. Doi: 10.2147/CIA.S56435.

18. Aloulou H, Mokhtari M, Tiberghien T, Biswas J, Phua C, Lin JHK, et al. Deployment of assistive living technology in a nursing home environment: methods and lessons learned. BMC Medical Informatics and Decision Making 2013; 13(42): 2-17. Doi: 10.1186/1472-6947-13-42.

19. Bayen UJ, Dogangün A, Grundgeiger T, Haese A, Stockmanns G, Ziegler J. Evaluating the Effectiveness of a Memory Aid System. Gerontology. 2013; 59(12):77-84. DOI: 10.1159/000339096

20. Giesbrecht EM, Mortenson WB, Miller WC. Prevalence and facility level correlates of need for wheelchair. seating assessment among long term care residents. Gerontology. 2012; 58(4): 378-384. Doi: 10.1159/000334819. Epub 2012 Jan 4. Doi: $10.1159 / 000334819$.

21. Bradley SM, Hernandez CR. Geriatric Assistive Devices. Am Fam Physician. 2011; 84(4): 405-411. Disponível em: http://www. aafp.org/afp/2011/0815/p405.html.

22. Huang $\mathrm{HC}$, Yeh $\mathrm{CH}$, Chen $\mathrm{CM}$, Lin YS, Chung $\mathrm{KC}$. Sliding and pressure evaluation on conventional and $\mathrm{V}$-shaped seats of reclining wheelchairs for stroke patients with flaccid hemiplegia: a crossover Trial. Journal of Neuro Engineering and Rehabilitation. 2011; 8(40): 3-8. Doi: 10.1186/1743-0003-8-40.

23. Brienza D, Kelsey S, Karg P, Allegretti A, Olson M, Schmeler M, et al. A Randomized Clinical Trial on Preventing Pressure Ulcers with Wheelchair Seat Cushions. J Am Geriatr Soc. 2010 December; 58(12): 2308-2314. Doi: 10.1111/j.1532-5415.2010.03168.x. 
24. Claude VC, Reinharz D, Deaudelin I, Garceau M,Talbot LR. Public telesurveillance service for frail elderly living at home, outcomes and cost evolution: a quasi experimental design with two follow-ups. Health and Quality of Life Outcomes 2006: 4(41): 1-10. PMID: 16827929.

25. Guitard P, Sveistrup H, Fahim A, Leonard C. Smart grab bars: a potential initiative to encourage bath grab bar use in community dwelling older adults. Assistive Technology: The Official Joornal. 2013; 25(3):139-48. Disponível em: http://www.ncbi.nlm.nih. gov/pubmed/24020152. PMID: 24020152.

26. Tchalla AE, Lachal F, Cardinaud N, Saulnier I, Bhalla D, Roquejoffre A, et al. Efficacy of simple home-based technologies combined with a monitoring assistive center in decreasing falls in a frail elderly population (results of the Esoppe study). Arch Gerontol Geriatr. 2012; 55(3): 683-9. PMID: 22743136.

27. Meira EC, et al. Tecnologia Assistiva de Vivências Musicais na recuperação vocal de idosos portadores de Doença de Parkinson. Rev. Bras. Geriatr. Gerontol. 2008; 11(3): 341-355. Disponível em: http://www.crde-unati.uerj.br/img tse/v11n3/capitulo3.pdf.

28. Peek ST, Wouters EJ, Van Hoof J, Luijkx KG, Boeije HR, Vrijhoef $\mathrm{HJ}$. Factors influencing acceptance of technology for aging in place: a systematic review. Int J Med Inform. 2014; 83(4): 23548. Doi: 10.1016/j.ijmedinf.

Publish in International Archives of Medicine.

International Archives of Medicine is an open access journal publishing articles encompassing all aspects of medical science and clinical practice. IAM is considered a megajournal with independent sections on all areas of medicine. IAM is a really international journal with authors and board members from all around the world. The journal is widely indexed and classified Q1 in category Medicine. 